\title{
The Role of Mass Media in Terrorism and Its Effect on Individuals
}

\author{
AhMET YiĞítalp TULGA* \\ ahmettulga@hotmail.com \\ ORCID ID: 0000-0001-7596-1269
}

\begin{abstract}
Nowadays terrorism is one of the biggest problems in the world. In particular, afterward the twin towers attack in the United States on September 11,2001, this has become a bigger problem for most of the countries in the world. Following in time the 9/11 terrorist attack, many governments launched a war against global terrorism in different parts of the world. Even the community psychology, which is not threatened by global terrorism, is negatively affected by extremist groups' coverage in media. Asian countries like Japan, Taiwan, and the Republic of Korea are the best examples of that. For this cause, in this research two linear regression are analyzed and Taiwanese newspaper text analyses are made. The main purpose and motivation of this research is to analyze the importance of media on terrorism and terrorist acts and how the media affects people's thoughts and psychology.
\end{abstract}

Keywords: Terrorism, Psychology, Opinion, Media, Mass media.

\section{Introduction}

Nowadays, the world is haunted by a ghost, the ghost of terrorism. In particular, the ghost of the terrorism that frightened most of the world after the twin towers attack in the United States on September 11, 2001. After this terrorist attack, a war against terrorism was launched by many governments around the World. ${ }^{1}$ This war against terrorism still continues today, becoming itself more severe and deep. ${ }^{2} \mathrm{Al}-$ though some governments have been suffering from terrorism for a long time, 9/11 has shown that terrorism is one of the biggest problems in the world. This problem has grown in scope and severity over time.

It is very useful to start with the definition of terrorism first. In this study, the definitions of terrorism of McCormick, and the Central Intelligence Agency (CIA) are used. According to the $\mathrm{CIA}^{3}$, "terrorism means premeditated, politically motivated

\footnotetext{
* PhD Student, National Sun Yat Sen University, Institute of Political Science.

1 Cemal Güzel, Silinen Yüzler Karşısında Terör, Ankara: Ayraç Yayınevi, 2002, p.5.

2 I.e. Syria, Philippines, Iraq and Somalia.

3 “Terrorism", 2007, Accessed 21 June 2020, https://www.cia.gov/news-information/cia-the-war-on-terrorism/
} 
violence perpetrated against non-combatant targets by subnational groups or clandestine agents, usually intended to influence an audience". In addition, McCormick describes global and domestic terrorism as planned use or threat of utilization of violence or aggression to accomplish a political goal by coercion or apprehension of a targeted audience. However, despite all these definitions, terrorism is a complicated phenomenon; therefore, it cannot be explained by just one case or event. Terrorism needs to be explained more fully and in-depth. ${ }^{4}$

Some scholars stated that modern terrorism began with the French Revolution in 1789. ${ }^{5}$ Other scholars such as Kaplan ${ }^{6}$ and Rapoport think that modern terrorism started in Russia at the end of $1880 .{ }^{7}$ Rapoport considers that terrorism consists of 4 main waves ${ }^{8}$ : Anarchist wave, anti-colonial wave, new left wave, and religious wave, all considered to be the forms of modern terrorism. ${ }^{9}$ I think that current terrorism is different than the four waves of terrorism. This current terrorism could be considered as the fifth wave of terrorism and I call this new wave as technological terrorism. Current terrorism varies from past acts of terrorism. Terrorism is a mobile, global threat in the modern era. Terrorist organizations or terrorists could easily create and increase fear through sophisticated communication technologies such as social media and mass media. Terrorist organizations are now better positioned to profit from current technological developments than any other suspect. The propensity to use software from governments makes it difficult for terrorist organizations to beat modern counter-terrorism tactics. ${ }^{10}$ Nevertheless, contemporary terrorist organizations vary because they do not see their organizations strong enough to fight a real war with their own or other countries. However, global terror and terrorist organizations that we face today are quite different from previous terrorist organizations. Alternatively, they prefer violence as the best way to fight for themselves.

Nowadays, it has been seen that terrorist organizations have also changed in the evolving world. Contemporary terrorism cannot be explained due to the lack of a common definition of terrorism. However, this new form of terrorism can be explained by the new wave of terrorism. With this new wave, it is seen that terrorist organizations have reached their target not only with guns, lone wolf attacks, or suicide attacks but also with propaganda on social media and mass media.

In recent years, numerous articles in the literature related to terrorism have been published, discussing its relation with social media- mass media such as Wilkinson's

terrorism-faqs.html?tab=list-3.

4 Gordon H. McCormick, “Terrorist Decision Making”, Annual Review of Political Science, 6/1 (2003).

5 Güzel, Silinen Yüzler, p.7.

6 Jeffrey Kaplan, “Terrorism's Fifth Wave: A Theory, a Conundrum and a Dilemma”, Perspectives on Terrorism, 2/2 (2008).

7 David C. Rapoport, The Four Waves of Modern Terrorism, Attacking Terrorism: Elements of a Grand Strategy, Washington, DC: Georgetown University Press, 2004, p.54.

8 Rapoport, The Four Waves, p.54.

9 Rapoport, The Four Waves, p.54.

10Samih Teymur, "A Conceptual Map for Understanding the Terrorist Recruitment Process: Observation and Analysis of DHKP/C, PKK, and Turkish Hezbollah Terrorist Organizations", PhD. Thesis, University of North Texas, 2007, p.105. 
research, and its effects on people's psychology such as Wessely's study. These articles contain various opinions. Despite numerous articles and opinions, still, there is no common idea written about all aspects of terrorism and how to strategically fight against these aspects of terror. Unfortunately, there is a gap in the literature. The most important reason for this gap is the lack of understanding the relationship between physical terrorism, media, and psychology.

This study examines the connection between physical and media terrorism and the effect of terrorism on civilians. This paper continues to assess the related research that helps to explain how the combination of physical terrorism and terrorism on mass media affect people. The effect of this combination on people's opinions would be explained with the traditional fear of crime theory.

This study has three main research questions. The first research question is "could new type of terrorist organizations achieve their goal ${ }^{11}$ without guns or weapons?" followed by the second one "How does the physical terrorism affect mass media?", and "how do the combination of these two elements influence people's psychology and daily life?". The main purpose and motivation of this research is to analyze the importance of media on terrorism and terrorist acts and how the media affects people's thoughts and psychology.

\section{Literature Review}

The literature review assesses research evidence in three areas. These are physical terrorism, media terrorism, and public opinion. These three areas are directly related to each other, and the understanding of this relationship helps us to comprehend to some extent the complex phenomenon of terrorism. Many studies in the literature such as Wilkinson and Dorothee have divided terrorism into two as domestic and global. Keeping in mind that today, the effects of domestic terrorist organizations and their actions are at the same time global, the distinction between domestics and global terrorism has disappeared, especially when contending with globalization. Therefore, this study did not differentiate between global and domestic terrorism and included all types of terrorism.

I think that physical terrorism, the media, and human psychology are directly related. Therefore, the study examines the aspect in three sub-sections. The first part points to the relationship between terrorism and social-mass media; the second part explores physical terrorism such as suicide bombs, lone wolf attacks, and coordinated attacks; and in the last part, the effects of the combination of media and physical terrorism on the psychology of people are investigated.

\section{Media Terrorism}

The first part of the literature review examines the relationship between terrorism

11Each terrorist organization has different goals, but the common main purpose of terrorist organizations is to demoralize the people and law enforcement agencies. 
and media in two sub-elements. First is the terrorism-mass media relationship ${ }^{12}$ and the second is the social media-terrorism relationship. ${ }^{13}$

The mass media-terrorism relationship has been going on for many years. The media enables individuals to interpret and evaluate events quickly. In this way, individuals simplify and structure the narrative of terrorist attacks and activities. ${ }^{14}$ The news frameworks in the media help the public to formulate their predictions and thoughts about terrorist events. Gerbner, Gross, Morgan, Signorielli, and Shanahan emphasize the role of the media in creating people's perceptions of social reality and setting the public agenda. ${ }^{15}$ At the same time, these scholars argue that the media plays a greater role in shaping public opinion. Similarly, Dorothee thinks that since September 11, London, Madrid, and Oklahoma terror attacks, the media has been playing a role in shaping the perception of terrorism by most people. ${ }^{16}$ Clearly, most of the academic studies have shown that television broadcasts, especially after the September 11 and Oklahoma terror attacks, cause post-traumatic stress disorder and depression on civilians. ${ }^{17}$

Wilkinson thinks that the relationship between media and terror is symbiotic. In addition to mass media and social media, videos, fake news, suicide attacks, and hitand-run tactics play important roles for contemporary terrorism. ${ }^{18}$ Like Wilkinson, Burke also thinks that the relation between media and terrorism is clear. Terrorist organizations gain popularity because of mass media. ${ }^{19}$ These scholars see the popularity of terrorist organizations as a consequence of increasing media attention on terrorist organizations.

On the other hand, some scholars see an increasing number of terrorist attacks as a consequence of the attention of media on terrorist organizations. Michael Jetter's research found that suicide missions receive significant media attention, which he believes could explain their increased popularity among terrorist groups. ${ }^{20}$ Jetter supports that media has to stop providing a free platform for terrorist's propaganda. ${ }^{21}$ Also, Yonah Alexander thinks that the media provides a useful tool for terrorist organizations' propaganda and psychological warfare. ${ }^{22}$

12Paul Wilkinson, "The Media and Terrorism: A Reassessment", Terrorism and Political Violence, 9/2 (1997).

13 Cori E Dauber, et al., "Call of Duty: Jihad -How the Video Game Motif Has Migrated Downstream from Islamic State Propaganda Videos", Perspectives on Terrorism, 13/3 (2019), p.27.

14 Pippa Norris, Montague Kern, and Marion R. Just, Framing Terrorism: Understanding Terrorist Threats and Mass Media, London: Routledge, 2003, p.54.

15George Gerbner, et al., "Growing up with Television: Cultivation Processes", Media Effects: Advances in Theory and Research, 1/2 (2002).

16 Dorothee C. Bruhn, "News Coverage on Terrorism: The Influence of Affect-Laden Images on Information Processing”,Undergraduate Thesis, University of Twente, 2009, p.16.

17Jennifer Ahern, et al., "Television Images and Psychological Symptoms after the September 11 Terrorist Attacks", Psychiatry: Interpersonal and Biological Processes, 65/4 (2002), p. 289-300.

18Wilkinson, "The Media and Terrorism ".

19Jason Burke, “'There Is No Silver Bullet': Isis, Al-Qaida and the Myths of Terrorism", The Guardian, August 2015.

20 Michael Jetter, “Terrorism and the Media”, IZA Discussion Paper, 2014, p.3.

21 Jetter, "Terrorism and the Media", p.4.

22 Yonah Alexander, “Terrorism, the Media and the Police”, Journal of International Affairs, 48 (1978). 
The second pillar of the relationship between media and terrorism is the relationship between social media and terrorism. Many terrorist organizations actively use social media to achieve their goals. For example, Al-Shabaab broadcasted live on twitter its armed attack to a shopping mall. ${ }^{23}$ Similarly, ISIS broadcasted live on the internet the killing of Turkish and Jordanian soldiers. ${ }^{24}$ Terrorist organizations aim to expand their wars with these strategies. At the same time, social media is used to create fear in the public. More than 100,000 tweets were posted during the ISIS invasion of Iraq and photographs were posted on the internet from the captured cities. ${ }^{25}$ Tweets created a fear over many city residents in Iraq and Syria and people began to flee from their cities. ${ }^{26}$ The same way, Perisin, Weinburg and Eubank think that modern forms of communication, social media, promote the spread of terrorism from one place to another. ${ }^{27}$

Most scholars seem to agree that social media and mass media continue to play an important role in the purposes of terrorism nowadays. Research has shown that social media, propaganda, fake news, and video can be successful without the use of a physical force, e.g., a fighting army. ${ }^{28}$ Secara states that new forms of social media like Youtube, Facebook, and Twitter play a very important role for terrorist organizations because they use these new forms of media to spread propaganda, training, recruitment, mobilization, coordination, and communication..$^{29}$ According to Secara (2015), ISIS uses the internet and social media differently than Al-Qaeda. She states that ISIS uses more social media and mass media but, Al-Qaeda mostly uses Internet forums. ${ }^{30}$

\section{Physical Terrorism}

One of the most important components of terrorism is physical terrorism. In this study, physical terrorism is divided into three groups which are suicide attack, lone wolf attack, and coordinated attack based on their effects, in addition to right-wing terrorism, a fourth group that has been on the rise in recent years.

Most scholars of terrorism studies argue that suicide attacks are the deadliest form of current terrorism. The costs of suicide are low, and these attacks attract more attention. Mroszczyk also believes that suicide bombings are more deadly and have a negative impact on civilians. ${ }^{31}$ Today, however, terrorist organizations are trying to

23 James P. Farwell, and Darby J. Arakelian, “Using Information in Contemporary War”, Parameters, 46/3 (2016), p.71.

24 Farwell and Arakelian, "Using Information", p.71.

25 Heather Marie Vitale, and James M. Keagle, "A Time to Tweet, as Well as a Time to Kill: Isis's Projection of Power in Iraq and Syria”, Defense Horizons, 77 (2014), p.1.

26 Anita Perešin, "Fatal Attraction: Western Muslimas and ISIS”, Perspectives on Terrorism, 9/3 (2015).

27 Leonard Weinberg and William L. Eubank, "Chapter 4 ", Countering Terrorism and Insurgency in the 21st Century: Strategic and tactical considerations, ed., James J. Forest, Wesport: Greenwood Publishing Group, 2007, p.150.

28Weinberg and Eubank, "Chapter 4", p.160.

29 Diana Secara, "The Role of Social Networks in the Work of Terrorist Groups. The Case of Isis and Al-Qaeda”, Research and Science Today, 3 (2015), p.77.

30 Secara, "The Role of Social”, p.77.

31 Joseph Mroszczyk, Chasing Ghosts: The Policing of Terrorism, New York: Oxford University Press, 2016, p.76. 
increase the lethality of suicide bombings and to reduce their costs in order to attract more attention. ${ }^{32}$

Burcu Alakoç agrees with Mroszczyk and in addition to suicide bombings, she focuses on the lone wolf attacks. Alakoç argues that the "lone wolf" attacks occur when individuals affected by the ideology or mission of any terrorist organization choose to perform the action on their own. ${ }^{33}$ One of the most important concerns in many countries such as Israel is the rise of such independent terrorist acts. With the technological developments in recent years, it facilitates the realization of the aspiration of people who aim to become "lone wolves" and suicide bombers but cannot participate in terrorist organizations. ${ }^{34}$

Some scholars focus on the coordinated terrorist attacks more than other physical types of terrorism. ${ }^{35}$ Avdan and Webb think that coordinated terrorist attacks affect people psychologically more than any other type of terrorist attack. ${ }^{36}$ They think that coordinated terrorist attacks have made them appear more threatening. ${ }^{37}$ Based on their research, terrorist attacks involving coordinated strikes on multiple targets are perceived to be more threatening than single-target attacks. According to Avdan and Webb (2018), fear is one of terrorism's fundamental characteristics and it is essential to understand how terrorism causes fear in order to acknowledge the political consequences of terrorism. Some of the actions of ISIS could be shown as examples of coordinated attacks. In 2015, there were terrorist attacks in three different countries on the same day. Three of them were organized by ISIS. ${ }^{38}$ Gilsinan thinks that this kind of terrorist attacks affects civilian's psychology and daily life negatively, because any individual could be a potential terrorist. ${ }^{39}$

\section{Public Opinion}

Physical terrorism and terrorism in the media have a great impact on people. After the physical acts of terror, people follow the events from the media sources, because they think that they could find the most detailed information from the media sources. ${ }^{40}$ These news are the most important element that affects public opinion. For example, since the terrorist attacks of September 11, the media has played an im-

32 Mrosczczyk, Chasing Ghosts, p.76.

33 Burcu Pinar Alakoc, "When Suicide Kills: An Empirical Analysis of the Lethality of Suicide Terrorism", International Journal of Conflict and Violence, 11 (2017), p.a493-a93.

34 Alakaoç, "When Suicide Kills", p.a493-a93.

35 Nazli Avdan and Clayton Webb, "The Big, the Bad, and the Dangerous: Public Perceptions and Terrorism", Dynamics of Asymmetric Conflict, 11/1 (2018); Jean-Paul Azam, "Suicide-Bombing as Inter-Generational Investment", Public Choice, 122/1-2 (2005); Jordan Galehan, "Instruments of Violence: Female Suicide Bombers of Boko Haram”, International Journal of Law, Crime and Justice, 58 (2019).

36 Avdan and Webb, "The Big, the Bad".

37 Avdan and Webb, “The Big, the Bad”.

38Kathy Gilsinan, "Terrorist Attacks on Schools Have Soared in the Past 10 Years", The Atlantic, December 17, 2014, p.3.

39Gilsinan, "Terrorist Attacks", p.4.

40Mamdoh Suleiman Al-Ameri, "Media and USF Students' Perception of Terrorism”, Graduate Theses, University of South Florida, 2013, p.76-84. 
portant role in shaping most people's perception of terrorism. ${ }^{41}$ Some scholars have emphasized the impact of physical terrorism on people. ${ }^{42}$ Rubin, Brewin, Greenberg, Hughes, Simpson, and Wessely argue that terrorist attacks could have a psychological effect on civilians. ${ }^{43}$ According to Rubin, Brewin, Greenberg, Hughes, Simpson, and Wessely (2007), the increased level of stress after terrorist acts causes a decrease in the sense of security and behavioral changes. On the other hand, some scholars such as Huff and Ketzer have focused on the effects of physical acts of terrorism and media on people. Huff and Kertzer think that political scientists have struggled to investigate the perception of violence among ordinary citizens. ${ }^{44}$ The authors' findings show how the language used describes incidents of violence, for which the mass media have considerable latitude, affecting people's ability to classify incidents as terrorism. ${ }^{45}$ Spencer supports Huff and Kertzer's idea about language. Spencer thinks that the media should be careful about word choices and language. Spencer suggests that the simple, seemingly trivial linguistic instruments, such as metaphors, can be used to pass at least certain understandings cognitively to the public. ${ }^{46}$ This specific type of wording can help to decrease the worry caused by the constitution of terrorism in the media. ${ }^{47}$

In recent years, terrorist attacks by similar terrorist organizations have caused different public reactions and most of the scholars seem to generally agree to that. ${ }^{48}$ The current literature shows that it is more traumatic for people living near where the terrorist attacks happened. Avdan and Webb argue that the threat perception is shaped by physical and personal proximity to terrorist attacks. ${ }^{49}$ They point out that the position of terrorist attacks and the race and nationality of the victims shape people's perception of threat. People are feeling more and more vulnerable when terrorist acts happen close to their country. When terrorism acts move away from their countries, the interest in terrorist acts decreases. Canada is an example of this. The September 11 attacks adversely affected the beliefs and behavior of people in Canada. ${ }^{50}$

41Christoph P. Pfeiffer, “Causalities and Casualties: Media Attention and Terrorism, 1970-2010”, Diskussionspapier, 127 (2012), p.12.

42 Shira Fishman, et al., "The Role of Individualistic and Collectivistic Goals in Support for Terrorist Attacks", Manuscript Submitted for Publication, 2007, p.22; Hazel K. Kwon, Monica Chadha, and Kirstin Pellizzaro, "Proximity and Terrorism News in Social Media: A Construal-level Theoretical Approach to Networked Framing of Terrorism in Twitter", Mass Communication and Society, 20/6 (2017).

43 James G. Rubin, et al. "Enduring Consequences of Terrorism: 7-month Follow-up Survey of Reactions to the Bombings in London on 7 July 2005", The British Journal of Psychiatry, 190/4 (2007).

44 Connor Huff, and Joshua D. Kertzer, "How the Public Defines Terrorism", American Journal of Political Science, 62/1 (2018).

45 Huff, and Kertzer, "How the Public"; Logan Macnair, "Linguistic and Narrative Trends Among Islamic State Videos and Magazines", Canadian Network for Research on Terrorism, Security, and Society, 2018, p.29.

46 Alexander Spencer, "The Social Construction of Terrorism: Media, Metaphors and Policy Implications", Journal of International Relations and Development, 15/3 (2012).

47 Edgar O'Ballance, Language of Violence: The Blood Politics of Terrorism, San Rafael, CA: Presidio Press, 1979, p.85; Bowman H. Miller, "Terrorism and Language: A Text-Based Analysis of the German Case", Studies in Conflict \& Terrorism, 9/4 (1987).

48 Poveda Criado and Miguel Ángel, “Journalism As A Terrorism Captation Weapon”, Revista de Comunicación de la SEECI, 49 (2019); Alan B. Krueger, and David D. Laitin, "Kto Kogo?: A Cross-Country Study of the Origins and Targets of Terrorism”, Terrorism, Economic Development, and Political Openness, 5 (2008).

49 Avdan and Webb, "The Big, the Bad".

50 Avdan and Webb, "The Big, the Bad". 
Yeniçeri and Dönmez try to explain terrorism with "lay theories". In order to see public opinion, they conducted a poll in Turkish Universities about terrorism. ${ }^{51}$ According to this survey, most of the students (69.5\%) think that terrorists are young people and $22.9 \%$ of the participants think that terrorists are illiterate and they couldn't graduate from any school. According to participants, religious terrorism is more dangerous than ideological and ethnic terrorism..$^{52}$ Similarly, Demirçivi conducted a survey about terrorism and its effect on civilians. Based on the result of this survey, women are more concerned about terrorism than men because after terrorist attacks women try to follow news about these terrorist attacks. Terrorist attacks have affected badly the psychological situation of the participants of the survey, using words like fear, violence, and threat to explain terrorism. ${ }^{53}$ Similar surveys have been conducted in other countries to understand people's thoughts obtaining related results. ${ }^{54}$ The research conducted by Brouard, Vasilopoulos, and Foucault shows great changes in the opinions of French people after the terrorist attacks in France in 2015 in Paris and 2016 in Nice. ${ }^{55}$ The most important of these idea changes are political. After the terrorist attacks, some of the left-wing sympathizers shifted towards the right-wing parties. ${ }^{56}$ After the terrorist attacks in 2015 and 2016, there has been an increase in the fear of terror in France. However, these attacks only had an impact on people's attitudes to security. ${ }^{57}$

\section{Research Design}

In the first stage of the research, the 6th wave survey of the world value survey is analyzed to examine the relationship between worry about terrorism and the media. The World Values Survey is a global network of social scientists researching and showing the changing values and their affect them on the world's sociopolitical life. ${ }^{58}$ In this study, the world value survey's questions on worry about terrorism (V184), social media-media, internet, and personal computer usage (V225) are examined. The unit of analysis' first step of this study is the individual level. The first analysis covers 22594 observations, 9 variables, in a period between 2010 and 2014.

After the first analysis, the subject becomes more specific and a second analysis is conducted. This analysis includes the terrorism index, worry about terrorism, and internet usage rates. This analysis tries to find the association between terrorism and

\footnotetext{
51 Zuhal Yeniçeri, and Ali Dönmez, "Perception of Terrorism and Terrorist: How Important Who Holds the Gun?”, Türk Psikoloji Dergisi, 23/62 (2008).

52 Yeniçeri and Dönmez, "Perception of Terrorism", p.100.

53 Gonca Aksoy and Fatma Nisan, "Türkiyedeki Terör Olayları Çerçevesinde Ankara Patlamaları Üzerine Bir İçerik Analizi Çalışması”, TRT Akademi, 2/3 (2001).

54 Randall K. Van Schepen, "Gerhard Richter's Critical Artistic Strategies: Politics, Terrorism and War", Messages, Sages, and Ages, 4/1 (2017).

55 Sylvain Brouard, Pavlos Vasilopoulos, and Martial Foucault, "How Terrorism Affects Political Attitudes: France in the Aftermath of the 2015-2016 Attacks", West European Politics, 41/5 (2018).

56 Brouard, Vasilopoulos and Foucault, "How Terrorism Affects".

57 Özlem Çapan Özeren, "Chapter 3”, Crisis File: Terror at Atatürk Airport, ed., Ömer Akgül, Cambridge: Cambridge Scholars Publishing, 2018, p.45.

58“World Values Survey: Round Six”, Inglehart, et al., Accessed 20 June 2019, http://www.worldvaluessurvey.org/ WVSDocumentationWV6.jsp.
} 
worry about terrorism-internet usage rate. The worry about the terrorism variable of this analysis is taken from the world value survey. The variable regarding internet use is taken from the world bank. Internet users variable shows individuals who have spent the last 3 months using the Internet (from any location). The Internet could be used through a screen, mobile phone, digital personal assistant, gaming console, digital TV. ${ }^{59}$ The terrorism index variable is taken from the Vision of Humanity and the Institute of Economics and Peace. The terrorism index measurements recognize security threats to the government, such as explosions, assaults or battle-related deaths, resistance groups, protests, coups, and violence or domestic/global terrorism. The rise of this variable indicates that there are security problems in the country. ${ }^{60}$

The unit of analysis of the second analysis is the country level. This analysis covers 52 countries and there are 4 variables. As a result, a cluster analysis involving 52 countries is conducted. The result is quite interesting and therefore Taiwan, which is included in both analysis, is chosen as the case analysis.

Within the scope of the case analysis, the news of Taiwan's “Taipei Times" and "Taiwan News" newspapers related to terrorism between 2014-2019 are examined, with a total of 40 news related to terrorism. The text analysis of these newspapers is made with the R program, a statistical software that is used for text analysis and sentiment analysis. As a popular open-source platform, $\mathrm{R}$ statistical software has a vast user community that develops and maintains a wide array of packages for text analysis. ${ }^{61}$ Finally, sentiment analysis of the news about terrorism in these newspapers during this period is made. "Sentimentr" package in R software is benefited for sentiment analysis. $^{62}$

\section{Results}

As a result of the first analysis, there is a highly significant and negative association between worry about terrorism and obtaining information from radio news. Secondly, there is a negative and highly significant association between obtaining information from daily newspapers and worry about terrorism. Thirdly, there is a positive and highly significant association between obtaining information from TV news and worry about terrorism.

Table 1. Summary Statistics

\begin{tabular}{|l|c|c|c|}
\hline Variables & $n$ & Mean & Std. Deviation \\
\hline Worry about terrorism (V184) & 22786 & 2.16 & 1.08 \\
\hline Obtaining information from printed magazine (V218) & 22786 & 2.70 & 0.98 \\
\hline
\end{tabular}

59 “Internet”, Max Roser, Accessed 21 June 2020, https://ourworldindata.org/internet.

60 Emanuele Marotta, and Alfredo Nunzi, "Chapter 19", International Encyclopedia of Political Science, ed., Bertrand Badie Dirk, Berg-Schlosser and Leonardo Morlino, Thousand Oaks, CA: SAGE Publications, Inc., 2011, p.2380.

61 Kasper Welbers, Wouter Van Atteveldt and Kenneth Benoit, “Text Analysis in R, Communication Methods and Measures", 11/4 (2017).

62 “Calculate Text Polarity Sentiment", Tyler Rinker, Accessed 21 June 2020, retrieve from https://cran.rproject. org/web/packages/sentimentr/sentimentr.pdf 


\begin{tabular}{|l|c|c|c|}
\hline Importance of religion (V9) & 22786 & 2.01 & 1.08 \\
\hline Obtaining information from Radio news (V220) & 22786 & 1.82 & 1.07 \\
\hline $\begin{array}{l}\text { Obtaining information from Daily newspaper } \\
\text { (V217) }\end{array}$ & 22786 & 1.91 & 1.04 \\
\hline Obtaining information from TV news (V219) & 22786 & 1.34 & 0.72 \\
\hline Obtaining information from mobile phone (V221) & 22786 & 1.59 & 1.00 \\
\hline Obtaining information from e-mail (V222) & 22786 & 1.98 & 1.13 \\
\hline Obtaining information from Internet (V223) & 22786 & 1.75 & 1.05 \\
\hline Personal computer usage (V225) & 22786 & 2.52 & 0.65 \\
\hline
\end{tabular}

Fourth, there is a positive and highly significant association between obtaining information from mobile phones and worry about terrorism. Fifth, there is also a negative and highly significant association between obtaining information from the internet and worry about terrorism. Sixth, there is a positive and highly significant association between personal computer use and worry about terrorism. Finally, there is a positive and highly significant association between the importance of religion, chosen as a control variable, and worry about terrorism. On the other hand, no statistical relationship was found between obtaining information from a printed magazine and worry about terrorism.

Table 2. Regression Analysis

\begin{tabular}{lc}
\hline \multicolumn{2}{c}{ Dependent variable: Worry about terrorism (V184) } \\
\hline Obtaining information from printed magazine (V218) \\
Obtaining information from Radio news (V220) & 0.004 \\
& $(0.008)$ \\
Obtaining information from Daily newspaper (V217) & $-0.027^{* * *}$ \\
& $(0.007)$ \\
Obtaining information from TV news (V219) & $-0.040^{* * *}$ \\
Obtaining information from mobile phone (V221) & $(0.007)$ \\
& $0.108^{* * *}$ \\
Obtaining information from e-mail (V222) & $(0.010)$ \\
Obtaining information from Internet (V223) & $0.065^{* * *}$ \\
Personal computer usage (V225) & $(0.008)$ \\
Importance of religion (V9) & $-0.019^{* *}$ \\
& $(0.009)$ \\
Constant & $-0.037^{* * *}$ \\
& $(0.011)$ \\
\hline Observations & $0.054^{\star * *}$ \\
\end{tabular}


Log Likelihood

Akaike Inf. Crit.

Note: ${ }^{\star} \mathrm{p}<0.1 ;{ }^{\star *} \mathrm{p}<0.05 ;{ }^{* \star} \mathrm{p}<0.01$

As a result of the first analysis, the study is further specified by the application of a second analysis that studies the country level. The dependent variable of the second analysis is the terrorism index. The independent variables are worried about terrorism and the population of internet users by country. As in the first analysis, the importance of religion is chosen as the control variable.

Table 3. Summary Statistics

\begin{tabular}{|l|c|c|c|}
\hline & $n$ & Mean & Std. Deviation \\
\hline Worry about terrorism & 52 & 62.12 & 21.91 \\
\hline Internet User & 52 & 58.23 & 22.73 \\
\hline terrorism & 52 & 5.58 & 2.59 \\
\hline A religious person & 52 & 67.15 & 22.01 \\
\hline
\end{tabular}

Table 4. Second Regression Analysis

\section{Dependent variable: Terrorism}

Worry about terrorism

$0.041^{\star * *}$

$(0.012)$

Internet User

$-0.078^{\star \star *}$

$(0.012)$

A religious person

Constant

(1.480)

Observations

52

$\mathrm{R} 2$

0.686

Adjusted R2

0.666

Residual Std. Error

$1.493(\mathrm{df}=48)$

F Statistic $34.965^{\star * \star}(\mathrm{df}=3 ; 48)$

Note: ${ }^{*} \mathrm{p}<0.1 ;{ }^{* *} \mathrm{p}<0.05 ;{ }^{* *} \mathrm{p}<0.01$

As expected, after the second analysis, there is a positive and highly significant association between terrorism and worry about terrorism. Secondly, a negative and highly significant association was found between the population of internet users and terrorism. Finally, no statistical relationship was found between the control variable and terrorism. With the scope of these analysis results, a cluster analysis was prepared. 


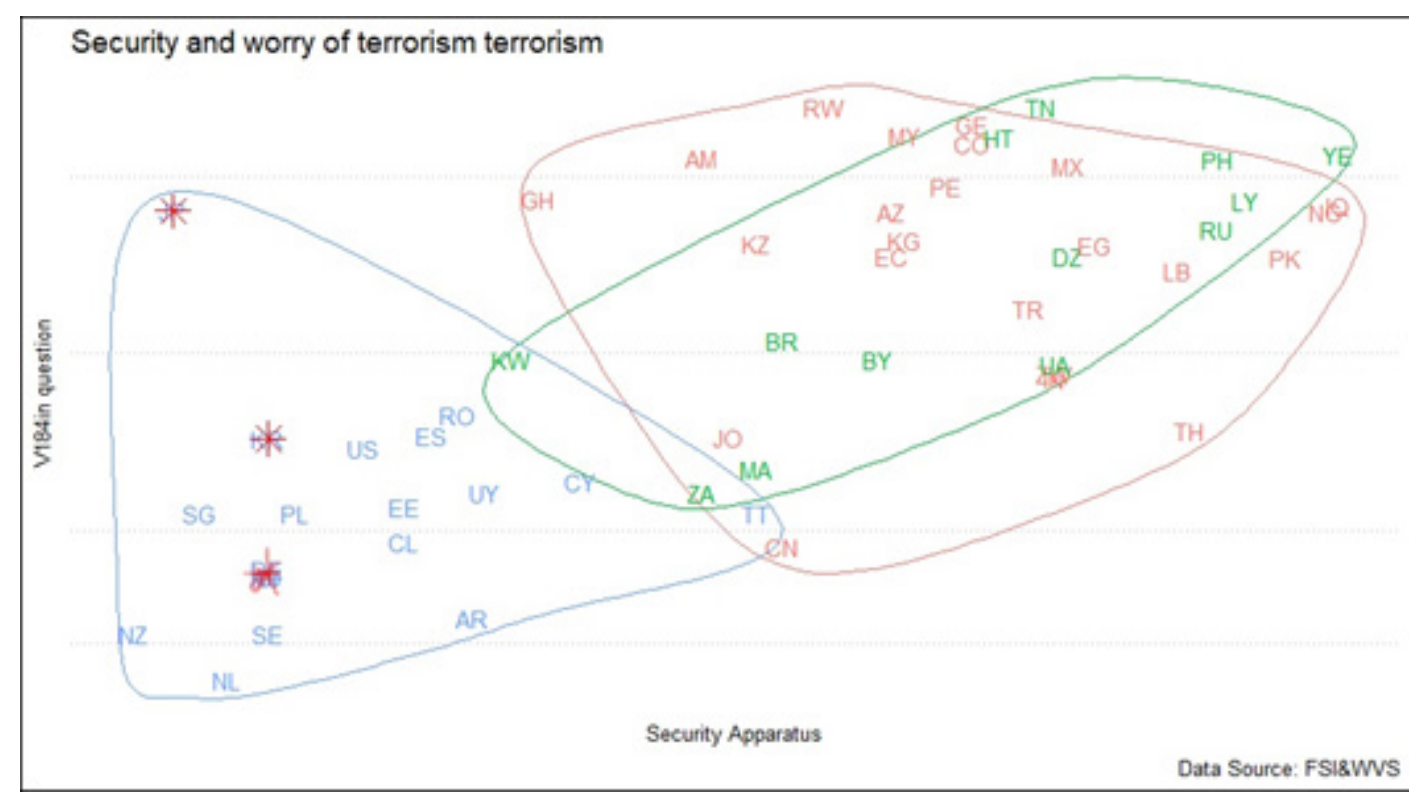

Figure 1. Cluster Analysis

As a result of cluster analysis, worry about terrorism results of countries with low terrorism index are quite high, which is the case of Taiwan. For this reason, the news about the terrorism of the two Taiwanese newspapers in a certain period of time is examined.

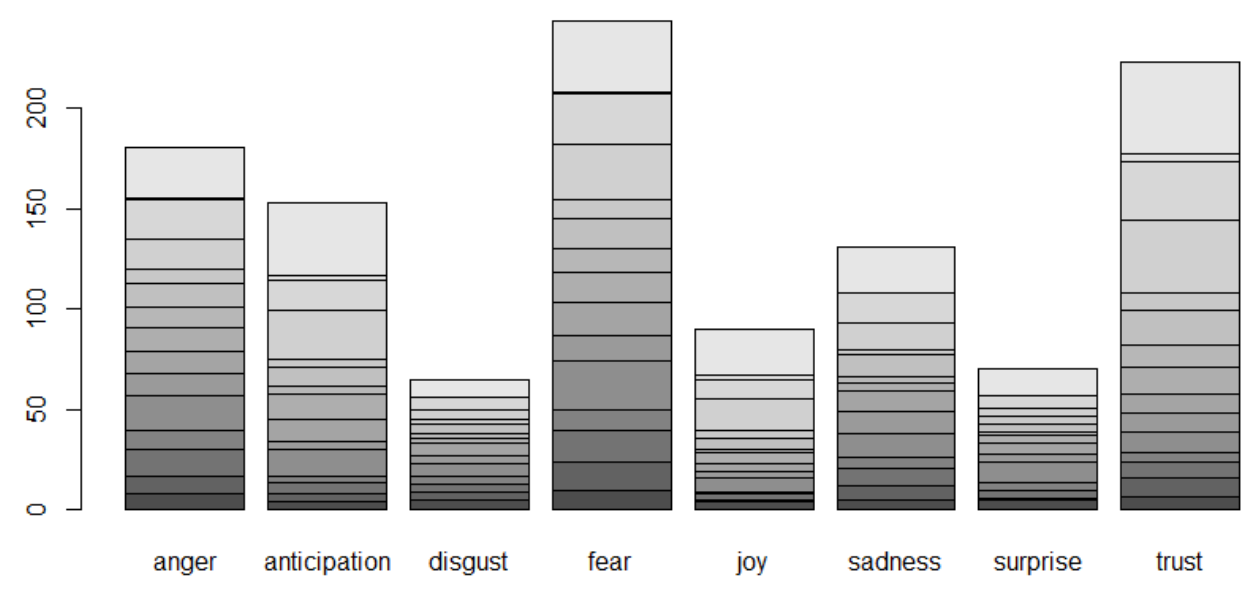

Figure 2. Sentiment Analysis

As a result of sentiment analysis of these two newspapers, it is revealed that the highest sentiment is fear. Finally, the most used words are found in these news. 


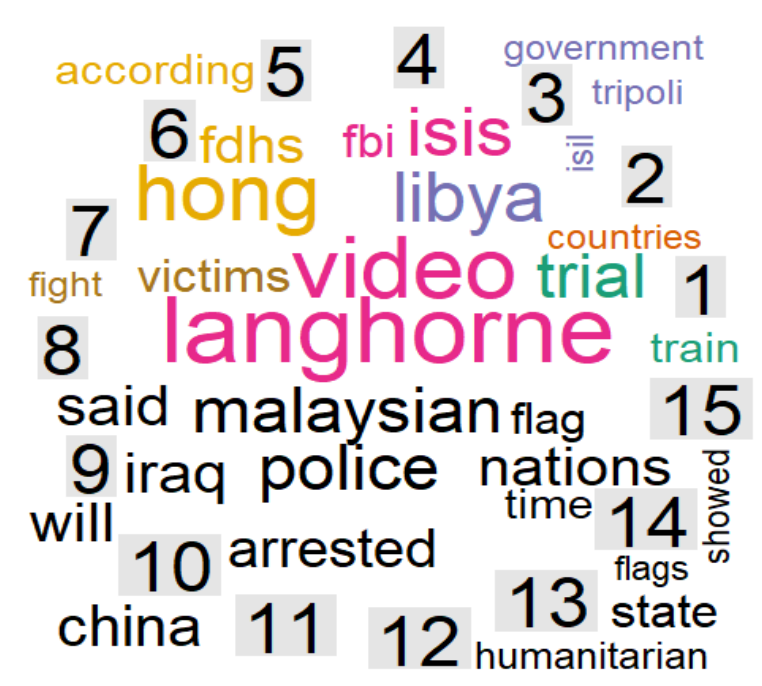

Figure 3. Most Common Words in These News

\section{Conclusion}

Although many studies have been done on different aspects ${ }^{63}$ of terrorism, currently no investigations have been conducted to ascertain how these different aspects of terrorism can be categorized into two distinct types: physical and mass media terrorism in countries that fight against terrorism. There are different views in the literature about different aspects of terrorism, but still, there is no common idea written about all aspects of terrorism, therefore a gap in the literature. The main purpose of this research is to fill these gaps in the literature. The other aim and purpose of this work is to examine the importance of media to extremism and terrorist acts, and how the interaction between physical terrorism and mainstream media influences people's thinking and psychology.

Four main findings are reached in this study. First, there is a direct relationship between media-terrorism and people's psychology, feelings, and behavior. The second finding is that news about terrorism are as effective as physical terrorism in influencing people positively or negatively. The third finding is that modern terrorist organizations use the media very effectively. The last finding is that terrorist organizations affect the psychology and thoughts of people through mass media.

Although countries such as Taiwan, Japan, and Korea face very few terrorist acts, their worry about terrorism is quite high. Likewise, the population of internet users of these three countries is quite high. Therefore, in order to understand the reason behind this worry, the news of the newspapers about terrorism is analyzed with the text analysis method. In this analysis, Taiwan is chosen as a case study.

In this context, the news related to the terrorism published by the "Taipei Times" and "Taiwan news" newspapers in English between 2014-2019 are analyzed. As a result of 
the text analysis made with the $\mathrm{R}$ computer program, the most dominant sentiment in the news of these newspapers is fear. Then the causes of this fear are investigated. Armed, conspiracy, suicide, tactics, threat, attack, chaos, deadly, explosion, bomb, and bomber words used in this news, and these words have the highest fear score inside these news. This study understands that these words create fear in the media.

Another finding reaches as a result of the text analysis, which is that ISIS is one of the most used words in these news (Figure 3). However, it is surprising that Taiwan,a country away from the ISIS threat, seems to be affected by the ISIS effect. As a result of the analysis, it is revealed that the media plays an important role in the spread of this threat.

Traditional fear of crime theory is used in this study making the findings of this literature review more meaningful. Based on this theory, crime is frequently the fundamental premise of many countries' highest-grossing films, top-rated television shows, bestselling novels, and most popular video games. Typically, stories of criminal events take the lead among television and internet news sources and are often considered to be the most widely viewed. Many people become really obsessed with violence. Although violence has the potential to fascinate, it also can frighten. The same shows and news stories that keep the public glued to their TV, also make a lot of people too scared of leaving their properties. Citizens frequently alter their habits, attitudes, and even places of residence due to fear of crime. ${ }^{64}$ This theory is very useful to demonstrate the effects of the combination of terrorism on the media and physical terrorism on people's opinions, behavior, and psychology.

The results of this study may reveal important information that can be used by government leaders to fine-tune their existing organizational policies and strategies in their fight against terrorism. However, there is still a big limitation in the literature. The biggest difficulty and limitation faced is the lack of a common definition of terrorism.

The biggest limitation of the study is the relatively little use of the qualitative research method in this research. Deeper information can be obtained if more qualitative research is used in future studies such as face-to-face interviews. It is quite possible to get more and effective information about the subject with the mixed-method approach.

Another limitation is the low number of news. Only 40 news were analyzed in this study due to the low number of English news. However, in future studies, English news of Japanese and Korean newspapers can also be analyzed to increase the number of news.

The overall conclusion regarding the terrorism literature is that there is no general consensus on the future of terrorism studies and that there is a lot of room for improvement in the research in the field of terrorism.

64 Robert W. Taylor, Eric J. Fritsch, and John Liederbach, Digital Crime and Digital Terrorism, New Jersey: Prentice Hall Press, 2014, p.97. 


\section{References}

Ahern, Jennifer, Sandro Galea, Heidi Resnick, Dean Kilpatrick, Michael Bucuvalas, Joel Gold, and David Vlahov. "Television Images and Psychological Symptoms After the September 11 Terrorist Attacks". Psychiatry: Interpersonal and Biological Processes. 65/4 (2002): 289-300.

Aksoy, Gonca Pervin, and Fatma Nisan. “Türkiyedeki Terör Olayları Çerçevesinde Ankara Patlamaları Üzerine Bir İçerik Analizi Çalışması”. TRT Akademi. 2/3 (2001): 134-158.

Alakoc, Burcu Pinar. "When Suicide Kills: An Empirical Analysis of the Lethality of Suicide Terrorism". International Journal of Conflict and Violence (IJCV). 11 (2017): a493-a93.

Al-Ameri, Mamdoh Suleiman. "Media and USF Students' Perception of Terrorism". Graduate Theses and Dissertations, University of South Florida, 2013, http:// scholarcommons.usf.edu/etd/4429.

Alexander, Yonah. "Terrorism, the Media and the Police". Journal of International Affairs. 48 (1978): 101-13.

Andersen, Robert, and Robert Brym. "How Terrorism Affects Attitudes Toward Democracy: Tunisia in 2015". Canadian Review of Sociology/Revue Canadienne de Sociologie. 54/4 (2017): 519-529.

Avdan, Nazli, and Clayton Webb. "The Big, the Bad, and the Dangerous: Public Perceptions and Terrorism". Dynamics of Asymmetric Conflict. 11/1 (2018): $3-25$.

Azam, Jean-Paul. "Suicide-Bombing as Inter-Generational Investment". Public Choice. 122/1-2 (2005): 177-98.

Brouard, Sylvain, Pavlos Vasilopoulos, and Martial Foucault. "How Terrorism Affects Political Attitudes: France in the Aftermath of the 2015-2016 Attacks". West European Politics. 41/5 (2018): 1073-1099.

Bruhn, Dorothee C. "News Coverage on Terrorism: The Influence of Affect-Laden Images on Information Processing". Undergraduate Thesis, University of Twente, 2009.

Burke, Jason. “There is No Silver Bullet': Isis, Al-Qaida and the Myths of Terrorism”. The Guardian, 19th of August 2015. Retrieved from https://www.theguardian. com/world/2015/aug/19/isis-al-qaida-myths-terrorism-war-mistakes-9-11

Central Intelligence Agency. “Terrorism”. 2007. Accessed 21 June 2020, Retrieved from, https://www.cia.gov/news-information/cia-the-war-on-terrorism/terrorism faqs.html?tab=list-3.

Criado, Poveda, and Miguel Ángel. "Journalism as a Terrorism Captation Weapon". Revista de Comunicación de la SEECI. 49(2019): 59-80.

Dauber, Cori E., Mark D. Robinson, Jovan J. Baslious, and Austin G. Blair. "Call of Duty: Jihad-How the Video Game Motif Has Migrated Downstream from Islamic State Propaganda Videos". Perspectives on Terrorism. 13/3 (2019).

Farwell, James P., and Darby J. Arakelian. "Using Information in Contemporary War". Parameters. 46/3 (2016). 
Fishman, S., et al. "The Role of Individualistic and Collectivistic Goals in Support for Terrorist Attacks". Manuscript Submitted for Publication. 2007.

Galehan, Jordan. "Instruments of Violence: Female Suicide Bombers of Boko Haram". International Journal of Law, Crime and Justice. 58 (2019): 113-23.

Gerbner, George, Larry Gross, Michael Morgan, Nancy Signorielli, and James Shanahan. "Growing up with Television: Cultivation Processes". Media Effects: Advances in Theory and Research. 1/2 (2002): 43-67.

Gilsinan, Kathy. "Terrorist Attacks on Schools Have Soared in the Past 10 Years". The Atlantic, December 17, 2014.

Güzel, Cemal. Silinen Yüzler Karşısında Terör. Ankara: Ayraç Yayınevi, 2002.

Huff, Connor, and Joshua D. Kertzer. "How the Public Defines Terrorism". American Journal of Political Science. 62/1 (2018): 55-71.

Inglehart, R., C. Haerpfer, A. Moreno, C. Welzel, K. Kizilova, J. Diez-Medrano, M. Lagos, P. Norris, E. Ponarin and B. Puranen. "World Values Survey: Round Six”. Access 20 June 2019. Retrieved from http://www.worldvaluessurvey.org/ WVSDocumentationWV6.jsp.

Jetter, Michael. “Terrorism and the Media”. IZA Discussion Paper, 8497 (2014): 3-20. Kaplan, Jeffrey. “Terrorism's Fifth Wave: A Theory, a Conundrum and a Dilemma”. Perspectives on Terrorism. 2/2 (2008): 12-24.

Krueger, Alan B., and David D. Laitin. "Kto kogo?: A Cross-Country Study of the Origins and Targets of Terrorism". Terrorism, Economic Development, and Political Openness. 5 (2008): 148-173.

Kwon, K. Hazel, Monica Chadha, and Kirstin Pellizzaro. "Proximity and Terrorism News in Social Media: A Construal-Level Theoretical Approach to Networked Framing of Terrorism in Twitter". Mass Communication and Society. 20/6 (2017): 869-894.

Macnair, Logan. "Linguistic and Narrative Trends Among Islamic State Videos and Magazines". Canadian Network for Research on Terrorism, Security, and Society. (2018): 80-120.

Madhumitha, Dharmapuri Selvakumar. "Terrorism in Media Land". Mass Communication and Society. (2017): 32-67.

Marotta, Emanuele and Alfredo Nunzi. “Chapter 19”. In International Encyclopedia of Political Science. Ed., Bertrand Badie Dirk, Berg-Schlosser and Leonardo Morlino. Thousand Oaks, CA: SAGE Publications, Inc., 2011.

McCormick, Gordon H. “Terrorist Decision Making”. Annual Review of Political Science. 6/1 (2003): 473-507.

Miller, Bowman H. “Terrorism and Language: A Text-Based Analysis of the German Case". Studies in Conflict \& Terrorism. 9/4 (1987): 373-407.

Mroszczyk, Joseph. Chasing Ghosts: The Policing of Terrorism. New York: Oxford University Press, 2016.

Norris, Pippa, Montague Kern, and Marion R Just. Framing Terrorism: Understanding Terrorist Threats and Mass Media. London: Routledge, 2003. 
O’Ballance, Edgar. Language of Violence: The Blood Politics of Terrorism. San Rafael, CA: Presidio Press, 1979.

Özeren, Özlem Çapan. “Chapter 3”. Crisis File: Terror at Atatürk Airport. Ed., Ömer Akgül. Cambridge: Cambridge Scholars Publishing, 2018.

Perešin, Anita. "Fatal Attraction: Western Muslimas and ISIS". Perspectives on Terrorism. 9/3 (2015): 21-38.

Pfeiffer, Christoph P. "Causalities and Casualties: Media Attention and Terrorism, 1970-2010”. Diskussionspapier. 127(2012).

Rapoport, David C. The Four Waves of Modern Terrorism. Attacking Terrorism: Elements of a Grand Strategy. Washington, DC: Georgetown University Press, 2004.

Rinker, Tyler. "Calculate Text Polarity Sentiment”. Accessed 21 June 2020, retrieved from https://cran.rproject.org/web/packages/sentimentr/sentimentr.pdf.

Roser, Max, Hannah Ritchie and Esteban Ortiz-Ospina. "Internet". Accessed 21 June 2020, Retrieved from: 'https://ourworldindata.org/internet'.

Rubin, G. James, et al. "Enduring consequences of terrorism: 7-month follow-up survey of reactions to the bombings in London on 7 July 2005". The British Journal of Psychiatry. 190/4 (2007): 350-356.

Secara, Diana. “The Role of Social Networks in the Work of Terrorist Groups. The Case of Isis and Al-Qaeda”. Research and Science Today. 3 (2015): 77.

Spencer, Alexander. “The Social Construction of Terrorism: Media, Metaphors and Policy Implications". Journal of International Relations and Development. 15/3 (2012): 393-419.

Taylor, Robert W., Eric J. Fritsch, and John Liederbach. Digital Crime and Digital Tterrorism. New Jersey: Prentice Hall Press, 2014.

Teymur, Samih. "A Conceptual Map for Understanding the Terrorist Recruitment Process: Observation and Analysis of DHKP/C, PKK, and Turkish Hezbollah Terrorist Organizations”. PhD. Thesis, University of North Texas, 2007.

Van Schepen, Randall K. “Gerhard Richter's Critical Artistic Strategies: Politics, Terrorism and War". Messages, Sages, and Ages. 4/1 (2017): 7-23.

Vitale, Heather Marie, and James M Keagle. "A Time to Tweet, as Well as a Time to Kill: Isis's Projection of Power in Iraq and Syria”. Defense Horizons. 77 (2014): 1.

Weinberg, Leonard, and William L. Eubank. "Chapter 4". Countering Terrorism and Insurgency in the 21st Century: Strategic and Tactical Considerations. Ed., James J. Forest. Wesport: Greenwood Publishing Group, 2007.

Welbers, Kasper, Wouter Van Atteveldt and Kenneth Benoit. "Text Analysis in R., Communication Methods and Measures”. 11/4 (2017): 245-265.

Wilkinson, Paul. “The Media and Terrorism: A Reassessment”. Terrorism and Political Violence. 9/2 (1997): 51-64.

Yeniçeri, Zuhal, and Ali Donmez. "Perception of Terrorism and Terrorist: How Important Who Holds the Gun?”. Türk Psikoloji Dergisi. 23/62 (2008): 93-107. 
İNSAN\&İNSAN, Y11/Year 7, Say1/Issue 25, Yaz/Summer 2020, 47-64

DOI: https://doi.org/10.29224/insanveinsan.695346

\title{
Kitle İletişim Araçlarının Terörizmdeki Rolü ve Bireyler Üzerindeki Etkisi
}

\author{
AHMET YiĞítALP TULGA
}

Öz: Günümüzde terörizm dünyanın en büyük sorunlarından bir tanesidir. Özellikle, 11 Eylül 2001 yılında Amerika'da ikiz kulelere gerçekleştirilen terör saldırısı sonrasında, bu sorun dünyadaki çoğu ülke için çok daha büyük bir sorun haline geldi. 11 Eylül terör saldırlarının ardından dünyanın birçok ülkesi küresel terörizme karşı bir savaş başlattı. Küresel terörizm tarafindan tehdit edilmeyen ülkelerin vatandaşları bile aşırılık yanlısı grupların medyada yer alan propagandalarmdan ve haberlerinden olumsuz etkilenmektedir. Japonya, Tayvan ve Kore Cumhuriyeti gibi Asya ülkeleri bu durumun en güzel örneklerindendir. Bu kapsamda hazırlanan bu araştırmada iki analiz ve metin analizi yapılmıştır. Bütün bu analizler $R$ programlama dili ile gerçekleştirilmiştir. Bu araştırmanın iki temel amacı ve motivasyonu vardır. Birincisi, medyanın terörizm ve terörist eylemler üzerindeki önemini göstermek ve çalışmanın ikinci temel amacı ise medyanın insanların düşüncelerini ve psikolojisini nasıl etkilediğini analiz etmektir.

Anahtar kelimeler: Terörizm, Medya, Psikoloji, Kitle iletişim araçları. 